\title{
EVALUATION OF COST EFFECTIVENESS OF NATIONAL PROGRAMME FOR CONTROL OF BLINDNESS IN DIBRUGARH DISTRICT.
}

Nasrin Banu Laskar.

1. Associate Professor, Department of Community Medicine, Sikkim Manipal Institute of Medical Sciences (SMIMS) and Central Referral Hospital, Tadong, Gangtok, Sikkim.

\section{CORRESPONDING AUTHOR:}

Dr. Nasrin Banu Laskar, Associate Professor, Department of Community Medicine, Sikkim Manipal Institute of Medical Sciences (SMIMS) and Central Referral Hospital (CRH), $5^{\text {th }}$ Mile, Tadong, Gangtok, Sikkim, India- 737102.

E-mail: nasrinbanu11@gmail.com

BACKGROUND: 90\% of the world's blindness is avoidable and avoidable blindness is responsible for significant social and economic implications both at the individual and global level. OBJECTIVE: To analyze the cost of different components of the National Programme for Control of Blindness and assess the cost effectiveness of the Programme METHOD: An observational study was conducted in Dibrugarh District of Assam from the period of July 2009 to June 2010 for assessing the cost effectiveness of the National Programme for Control of Blindness. In the study, the cost of the inputs were considered under four broad categories, viz. Capital costs, recurrent costs, Prime/variable costs and Fixed costs. The cost incurred by the provider was taken as the actual cost of delivery of different component of services to the patients, which was calculated from the costs of Labour, material and capital costs using the time utilization pattern (WHO 1990). RESULT: The District Blindness Control Society, Dibrugarh had spent 58.93 \% on fixed heads of which 65.86\% had been spent for cataract surgery. The medical care cost was found to be Rs.425 for ICCE, Rs. 675 for ECCE+IOL and Rs.225 for refractive error correction. The patient wise provider cost was estimated to be Rs. 519 for ICCE, Rs. 769 for ECCE+IOL implantation and Rs. 319 for spectacle correction of refractive error. CONCLUSION: NPCB is a cost effective means of reducing the social as well as economic burden of avoidable blindness.

KEY WORDS: Avoidable blindness, NPCB, cost effective.

INTRODUCTION: Vision is one of the most cherished senses and its importance in our lives is axiomatic. The WHO has estimated that globally, there are 45 million people who are blind, a figure that is expected to increase to approximately 76 million by the year $2020 .^{1}$

This rising tide of blindness can be attributed primarily to the important demographic changes that have taken place in recent decades in the developing countries that has resulted in an increase in life expectancy at birth as well as an increase in the size of the adult population. The vast majority of the world's blind live in developing countries, where infection, malnutrition and lack of eye care give rise to a high proportion of blindness, particularly in the rural population. 
Estimates indicate that in excess of $90 \%$ blindness exists in the developing countries, with Sub-Saharan Africa and India accounting for a large proportion. Childhood blindness is the second largest cause of blind person years. Approximately $40 \%$ of childhood blindness is avoidable. ${ }^{2}$

Avoidable blindness is responsible for significant social and economic implications both at the individual and global level. The cost of education rehabilitation and lost productivity adds to impact, which is more upon those who are economically deprived. ${ }^{3}$

Needless blindness and poor vision can be eliminated only if people have access to sight saving health care. This ensures social as well as economic progress of a nation. The first organized national effort to control blindness in India was the National Programme for Trachoma launched in 1963. The National Programme for Control of Blindness (NPCB) was formally launched in 1976 with the goal of reducing the prevalence of blindness to $0.3 \%$ by 2000 . The strategies of NPCB were to identify the high prevalence states for special attention, up-gradation of facilities and skills, involving the private sector including NGOs and giving the programme the character of a movement through the establishment of a partnership institution in the form of societies committed to the goal of the programme. ${ }^{4}$ Cataract being a curable cause of blindness accounting for the maximum disease burden, the programme has given highest priority to cataract removal. ${ }^{5}$

In North Eastern India the Programme has been implemented in all states since 1998 onwards. However since it's inception no evaluation had been done in the region. Due to the current changes in the economic situation and considering the rising burden of the disease to the society, evaluation of the programme has become a public health priority. Accordingly this study was undertaken to asses the cost effectiveness of the Programme in Dibrugarh district of Assam, with following

OBJECTIVE: To analyze the cost of different components of the National Programme for Control of Blindness and assess the cost effectiveness of the Programme.

MATERIALS AND METHODS: The study was an observational study and was conducted during the period of July 2009 to June 2010 in Dibrugarh District which is located in the eastern part of Assam. All the data were collected by the investigator herself. For the evaluation, all the financial records and reports related to the Programme were analyzed using suitably designed cost analysis formats. While collecting the cost data, the basic aim was to identify all the inputs to the NPCB and to quantify them. During costing procedure, up to the smallest monetary unit (Re. 1/-) was taken to minimize the rounding error.

In the study, the cost of the inputs were considered under four broad categories, viz. Capital costs, recurrent costs, Prime/variable costs and Fixed costs. For calculation of capital costs, capital goods were identified followed by their costing. Capital goods were defined as those inputs that lasted more than 1 year. ${ }^{6}$ Cost for baseline training activities for health personnel that occur in long intervals, Jeep, two-wheelers etc were categorized under Capital Cost. For this study, the average annual costs of capital goods were determined in the following manner:

- Current (replacement) costs (C) of purchasing them were identified.

- Estimated total number of working life $(\mathrm{N})$ in years assumed.

- Average annual costs of each capital items were established in terms of simple 'straight-line' depreciation: 


\author{
Current cost of Item \\ i.e. $\mathrm{C} / \mathrm{N}=$ \\ Working life
}

Recurrent Costs: Recurrent costs were defined as costs of those inputs that are used up in the course of a year and are usually purchased regularly. ${ }^{6}$ In NPCB, expenses in the following categories were considered as recurrent costs: Salaries and allowances of NPCB staff, Supplies like ocular drugs, IOLs, spectacles, chemical reagents, suture materials, Cost of vehicle operation and maintenance, Office maintenance, reorientation training programme etc.

The programme cost of production of different services could also be divided into two categories of cost: Prime/Variable Costs: They include costs of raw material to produce a service. ${ }^{7}$ Here the office expenditure, maintenance of vehicle, welfare of patients, printing of case cards, local purchase of medicines and miscellaneous expenditure are included. Fixed Costs: Costs, which do not vary with changes in volume of output, were put in this category. ${ }^{7}$ In NPCB they included salary and allowances, cost of vehicle, cost of equipments etc.

In this study, the cost incurred by the provider was taken as the actual cost of delivery of different component of services to the patients, which was calculated from the costs of Labour, material and capital costs using the time utilization pattern (WHO 1990). All costs were categorized as routine or overhead costs and calculated by dividing the overhead cost by the total number of patients for the year 2009-10.

\title{
RESULTS:
}

\section{COST ANALYSIS OF THE PROGRAMME}

(I) Expenditure of the Programme in the Financial Year 2009 - 10: The District Blindness Control Society, Dibrugarh had spent $58.93 \%$ on fixed heads of which $65.86 \%$ had been spent for cataract surgery. Of the variable cost, $96.83 \%$ had been utilized for the consumables (Table: 1 ).

\section{(II) Total Overhead Costs:}

The overhead costs of the programme were calculated by summation of capital costs, material costs and Labour costs as given. For estimation of material costs, the total cost incurred for Training, IEC/Publicity, Vehicle Maintenance, Equipment Maintenance and Contingencies was considered. The total amount spent for disbursement of salary and honorarium was Rs. 01, 60,000 (Labour Cost). The total overhead cost incurred by the programme was Rs. 3, 14,092 of which maximum expenditure (50.94\%) was incurred by Labour costs.

(III) Routine Service Costs: The routine service cost was estimated to be approximately Rs. 94/-

Routine Service Cost per visit $=\frac{\text { Total Overhead Cost-Training Cost }}{\text { Number of Visits }}$

(IV) Medical Care Cost:

Journal of Evolution of Medical and Dental Sciences/ Volume 2/ Issue 18/ May 6, 2013

Page 3020 
For the year 2009-10 a total of 2718 patients with cataract received treatment under the programme. It was observed that out of the 2718 patients, 42 patients underwent ICCE while 2676 patients underwent ECCE with IOL implantation. The medical care cost per treatment modality, incurred by DBCS, Dibrugarh was accordingly calculated and found to be Rs.425 for ICCE , Rs. 675 for ECCE+IOL and Rs.225 for refractive error correction.

Total Provider Costs: The patient wise provider cost (Total routine cost + total medical care cost) was estimated to be Rs. 519 for ICCE, Rs. 769 for ECCE+IOL implantation and Rs. 319 for spectacle correction of refractive error.

DISCUSSION AND CONCLUSION: As reported by MOHFW (2002), the routine service cost per patient per visit in the non- project states of the country were Rs. 79.8 The slight increase in the routine service cost in the present study may be attributed to the time gap between the two studies during which there might have been slight fluctuations in the monetary value.

Performing ECCE+IOL implantation for treatment of cataract in the current situation was found to be more cost effective as compared to the findings of cost benefit analysis of the World Bank assisted Cataract Control Project in India which revealed that the cost incurred in screening and then performing ICCE for a cataract patient in a base hospital was Rs. 1128 per operation. ${ }^{9}$

Thus it can be concluded that considering the cost effectiveness of NPCB in treating avoidable blindness by ECCE+IOL implantation and spectacle correction, its proper implementation in the district would greatly reduce the disease burden on families, in particular and society, in general, as blindness is not just a social deterrent but also a blow to the economy of the individual as well as the community.

\section{REFERENCES:}

1. World Health Organization (1997): The World Health Report; Report of the Director General. WHO. Geneva, Editorial.

2. World Health Organization (1973): Third World Health Assembly Resolution, WHA 3.22; Handbook of Resolutions and decisions of the World Health Assembly and Executive board; Vol 1, 1948- 1972, Geneva, WHO, 1973: pp: 98

3. Yorston David (1999): The Global Initiative, Vision 2020: The Right to Sight Childhood Blindness; Int. Journal of Community Eye Health, Vol 12(31): pp: 44.

4. Govt. of India, Annual Report (1997-98): Ministry of Health and Family Welfare.

5. Kishore J., National Health Programmes of India (National Policies and legislations related to health), 6th edition, 2006: pg: 267-272.

6. www.who.int/immunization_financing/data/about/terminology/en. Date accessed on 24.04.2013.

7. Thulasiraj D, Sivakumar AK, Journal of Community Eye Health, Vol.14 No.37 2002 pg:4-6

8. Ministry of Health and Family Welfare (2002): Report No.3 (Civil). 


\section{ORIGINAL ARTICLE}

9. Avtar Singh Dua, National Commission on Macroeconomics and Health, Ministry of Health and Family Welfare, Govt. of India, (September 2005), Background paper on Disease Burden in India, pp: 299 -305.

Table - 1. Calculation of total cost for DBCS, Dibrugarh during the financial year 2009-10

\begin{tabular}{|c|c|c|c|c|}
\hline \multicolumn{2}{|c|}{ Budget heads } & \multirow{2}{*}{$\begin{array}{l}\text { fixed cost } \\
\text { (Rs. in lakhs) } \\
\begin{array}{l}20,21,000 \quad(65.86 \\
\%)\end{array}\end{array}$} & \multirow{2}{*}{$\begin{array}{l}\text { variable costs } \\
\text { (Rs. in lakhs) } \\
---\end{array}$} & \multirow{2}{*}{$\begin{array}{l}\text { total costs (Rs. in } \\
\text { lakhs) }\end{array}$} \\
\hline Treatment & Cataract Surgery & & & \\
\hline expenses: & $\begin{array}{l}\text { Spectacle } \\
\text { Correction }\end{array}$ & $17,500(0.57 \%)$ & ---- & 17,500 \\
\hline \multicolumn{2}{|c|}{$\begin{array}{l}\text { Spectacles + SES* + Post. Operative } \\
\text { care }\end{array}$} & ---- & $3,877(0.18 \%)$ & 3,877 \\
\hline \multicolumn{2}{|c|}{ Consumables } & ---- & $\begin{array}{l}20,70,500(96.83 \\
\%)\end{array}$ & $20,70,500$ \\
\hline \multicolumn{2}{|c|}{ Equipment Maintenance } & ---- & $8,748(0.41 \%)$ & 8,748 \\
\hline \multirow{2}{*}{$\begin{array}{l}\text { Support } \\
\text { Activities: }\end{array}$} & IEC/Publicity & ---- & $4,500(0.21 \%)$ & 4,500 \\
\hline & Training & ---- & $26,573(1.24 \%)$ & 26,573 \\
\hline \multicolumn{2}{|c|}{ Vehicle Purchase } & $7,50,000(24.44 \%)$ & --- & $7,50,000$ \\
\hline \multicolumn{2}{|c|}{ Building Cost } & $1,20,000(3.91 \%)$ & ---- & $1,20,000$ \\
\hline \multicolumn{2}{|c|}{ Salary + Honorarium } & $1,60,000(5.21 \%)$ & --- & $1,60,000$ \\
\hline \multicolumn{2}{|c|}{ Contingency } & 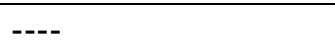 & $17,863(0.84 \%)$ & 17,863 \\
\hline \multicolumn{2}{|l|}{ TOTAL } & $\begin{array}{ll}30, & 68 \\
500(58.93 \%) & \end{array}$ & $\begin{array}{ll}21, & 38, \\
295(41.07 \%) & \end{array}$ & $52,06,795$ \\
\hline
\end{tabular}

*SES: School Eye Screening. 
Table - 2: Calculation of equivalent annual cost of capital goods by simple straight line depreciation method

\begin{tabular}{|l|l|l|l|}
\hline capital goods & $\begin{array}{l}\text { present market } \\
\text { value } \\
\text { (in rs.) (m) }\end{array}$ & $\begin{array}{l}\text { useful working equivalent annual } \\
\text { life } \\
\text { (in years) } \\
\text { (l) }\end{array}$ & $\begin{array}{l}\text { cost } \\
\text { (in rs.) } \\
\text { (m/l) }\end{array}$ \\
\hline $\begin{array}{l}\text { one generator (petrol } \\
\text { operated) }\end{array}$ & 18,550 & 10 & 1,855 \\
one steel table & 10 & 564 \\
$\begin{array}{l}\text { wardrobe without mirror } \\
\text { one van of dmu } \\
\text { building cost }\end{array}$ & 7,641 & 10 & 754 \\
& $7,50,000$ & 10 & 75,000 \\
$1,20,000$ & 10 & 12,000 \\
\hline Total (in rupees) & 100,174 \\
\hline
\end{tabular}

Table - 3: Total number of patient visits \& routine service costs for the financial year 2009-10

\begin{tabular}{|l|l|l|l|l|}
\hline \multicolumn{2}{|l|}{ Patients Registered } & $\begin{array}{l}\text { Number of visits by 1 } \\
\text { patient }\end{array}$ & $\begin{array}{l}\text { Total Number of } \\
\text { visits }\end{array}$ & $\begin{array}{l}\text { Routine Service Cost } \\
\text { per visit }\end{array}$ \\
\hline With Cataract & 2718 & 1 day & 2718 days & $\underline{314092-26573}$ \\
\cline { 1 - 1 } $\begin{array}{l}\text { With Refractive } \\
\text { Error }\end{array}$ & 350 & 1 day & 350 days & $\begin{array}{l}3068 \\
=\text { Rs. 93.71 } \\
=\text { Rs.94 (rounded off) }\end{array}$ \\
\hline Total & 3068 & 1 day & 3068 days & \multicolumn{2}{|l}{} \\
\hline
\end{tabular}


Table - 4: Medical care cost for the different treatment modality

\begin{tabular}{|c|c|c|c|}
\hline \multirow{2}{*}{ Heads of Expenditure } & \multicolumn{3}{|c|}{ Cost incurred per Treatment Modality (In Rs.) } \\
\hline & ICCE & ECCE + IOL & $\begin{array}{ll}\text { Refractive } & \text { Error } \\
\text { Correction } & \\
\end{array}$ \\
\hline Drugs \& Consumables & Rs. 150 & Rs. 200 & -------- \\
\hline Sutures & Rs. 50 & Rs. 50 & -------- \\
\hline Spectacles & Rs. 125 & Rs. 125 & Rs. 125 \\
\hline Transport \& POL & Rs. 100 & Rs. 100 & Rs. 100 \\
\hline $\begin{array}{l}\text { IOL/Viscoelastics } \quad \& \quad \text { addl. } \\
\text { Consumables }\end{array}$ & -------- & Rs. 200 & -------- \\
\hline TOTAL & Rs. 425 & Rs. 675 & Rs. 225 \\
\hline
\end{tabular}

Table - 5: Patient wise provider cost (icce/ ecce+ iol /spectacle correction)

\begin{tabular}{|c|c|c|c|c|}
\hline \multirow[b]{2}{*}{$\begin{array}{l}\text { TYPE OF } \\
\text { IMPAIRMENT }\end{array}$} & \multirow[b]{2}{*}{$\begin{array}{l}\text { Type of } \\
\text { Correction }\end{array}$} & \multicolumn{2}{|l|}{ COSTS (In Rupees) } & \multirow[b]{2}{*}{ TOTAL } \\
\hline & & $\begin{array}{l}\text { Routine Service cost } \\
\text { (per patient) }\end{array}$ & $\begin{array}{l}\text { Medical Care cost } \\
\text { (per patient) }\end{array}$ & \\
\hline \multirow{2}{*}{ Cataract } & ICCE & Rs. 94 & Rs. 425 & $\begin{array}{l}\text { Rs. } \\
519\end{array}$ \\
\hline & ECCE+IOL & Rs. 94 & Rs. 675 & $\begin{array}{l}\text { Rs. } \\
769\end{array}$ \\
\hline Refractive error & $\begin{array}{l}\text { Spectacle } \\
\text { correction }\end{array}$ & Rs. 94 & Rs. 225 & $\begin{array}{l}\text { Rs. } \\
319\end{array}$ \\
\hline
\end{tabular}

